Diabetologia (1997) 40: [Suppl 1]: I-V

\title{
Minutes of the 32nd General Assembly of the European Association for the Study of Diabetes
}

\section{Held in Mozart Hall in the Austrian Center Vienna, 4th September 1996 from 12.15-13.00 h}

\author{
Present: Drs. M Berger \\ UJ Eriksson \\ E Ferrannini \\ (President) \\ (Honorary Secretary) \\ (Editor-in-Chief, \\ Diabetologia) \\ J Nunes-Correa (Honorary Treasurer) \\ and 286 members
}

In welcoming everyone to the General Assembly Prof. Berger expressed his pleasure at seeing so many more members than in previous years. This was in line with the desire of the Executive Committee to involve the members more with the decision-making processes of the Association.

\section{Minutes, 31st General Assembly 1995}

After having asked the membership for approval of the Minutes of the 31st General Assembly, Dr. Berger and Dr. Eriksson signed the minutes as a correct record.

\section{Reports}

a) President: The President gave a brief report of the last 12 months. He reiterated his thanks to Dr. Hellerström for the tremendous success of last year's Meeting which had a record of 6,100 attendants.

At this year's Meeting there had been more than 6,000 attendants. Although this suggested a success, it could also encompass some dangers. The President pointed out that the character of the Association's meetings as a forum for scientific exchange must be maintained. The focus must be kept on successfully keeping up the scientific standards. In this context Dr. Berger said he would welcome feed-back on this Annual Meeting from the members.

Dr. Berger offered his preliminary thanks to Dr. Schernthaner and his colleagues.

The Scientists Training Courses which had been started by Dr. Alberti were continuing successfully. He thanked Dr. Eizirik for the excellent organisation of the course in Uppsala in August which was jointly organised and sponsored by the JDFI. With the participation of 5 scientists from the USA, this was felt to be a useful exchange for the young generation of researchers in the diabetic field.

The EASD/JDFI Oxford Conference in July had been another success, with the participation of 25 researchers and their fellows. The President thanked JDFI and Hoechst AG for their support to the Oxford Conference. The Industry Liaison Meeting had afforded a forum for discussing mutual interests and potential problems or conflicts. Many thanks had to go to Novo Nordisk, Germany and Novo Nordisk, Austria for their sponsorship which enabled the continuation of the Solidarity Fund. This provides members of economically or financially poor countries with the wonderful chance of being a member of the EASD and receiving the journal for free.

The Eli Lilly Fellowship would also continue, together with Glaxo and Bayer who had enabled the continuation of the travel support. Thanks must also go to the family Maria Carla Pedroli, 5 members of which had attended the Meeting, and to Hoechst for sponsoring the Minkowski award. This year the Albert Renold Fellowship of $£ 10.000$ was awarded without sponsorship to Dr. Bruce Verchère, the Eli Lilly/EASD Research Fellowship in Diabetes and Metabolism was given to Dr. Christine Huppertz and the Glaxo Wellcome/EASD Burden of Diabetes Research Fellowship was awarded to Dr. Andrea Natali.

There had been increasing concerns that diabetes research had not been adequately represented at the European Commission. Several attempts had been made to rectify the situation. On 19th January 1996 the EASD together with IDF Europe (Dr. P.H. Home) and Alfediam (Dr. Gerard Cathelineau) met in Brussels with Bruno Hansen, Director of the European Commission, to discuss potential ways of increasing the awareness of diabetes. The outcome of this meeting was a letter to Mme Cresson, Membre de la Commission Science, recherche et développement, and the document "Diabetes Research in Europe" which would be sent to all members of the EU Parliament. It was also decided to hold a meeting in Brussels in March 1997 to present to the EU delegates the importance of diabetes and the need for diabetes research. The summary will be published in Diabetologia.

Concerning the venues for the forthcoming Annual Meetings, Dr. Berger gave a brief overview of the cities where the EASD Meetings from the year 2000 onwards would be held:

Jerusalem

2001 Birmingham

2002 Budapest

2003 Paris (IDF Meeting) 
Asking for questions or comments at the end of his report, members expressed their support regarding the initiative of pointing out the importance of diabetes research to the EU, others thanked the Association for the free membership and receipt of the journal.

b) Honorary Treasurer: Dr. Nunes-Correa opened his report by thanking the officers of the EASD and the Secretariat for their help.

He reported that in 1993 the assets had been roughly $£ 1$ million and in $1995 £ 619,000$, the reduction being due to the fact that the Association had decided to increase its spending on training and research activities. The assets, in his opinion, should be kept at a prudent, not excessive, level, with a balance between income and expenses being aimed at. Regarding 1995 there was a considerable increase in the amount received for membership fees and a substantial increase in donations. The EASD Düsseldorf surplus was received during 1995. Regarding EASD expenses, while travel and office equipment costs increased, the actual running costs remained stable. Annual meeting expenses were substantially higher, due to the costs of invited speakers. A loan of $£ 50.000$ had been granted to the local organisers in Vienna. The number of travel and stayment grants had increased and more prizes and fellowships had been awarded.

There was an increase in the costs of Diabetologia and the EASD contribution to the Editorial Office, with the Solidarity Fund representing a heavy financial commitment for the EASD. The expenses of the Scientists Training Course remained approximately the same and those of the Post Graduate Education Subcommittee diminished. By the end of 1995 the fixed assets had been redistributed which would hopefully protect the currency from upheavals.

Although there would be no Annual Meeting and therefore no surplus the following year, Dr. Nunes-Correa felt sure the financial situation of the EASD would continue to be healthy, since the membership fees had almost covered the costs of Diabetologia and the office running costs. Also the gradual increase in sponsorships and donations over the previous 3 years strengthened this feeling of confidence.

The President thanked Dr. Nunes-Correa and asked the assembly if there were any questions. When none arose, he asked the Honorary Auditors if the accounts were in order. After Dr. Guillesseau gave his approval, the General Assembly unanimously accepted the accounts.

c) Honorary Secretary: Dr. Eriksson began by explaining that due to a change in the format of the meeting - an increase in the length from $3^{1} / 2$ to 4 days - there had been a record number of State of the Art Symposia (7) and the number of poster sessions had been increased from 3 to 4 . State of the Art Lectures (6) and Meet-the-Expert Sessions (10) had remained the same.

The poster sessions had been changed so that the authors needed only to be present at two sessions, during the other two they had the possibility to discuss other posters. The total number of abstracts received was the highest ever, 1.681; a record was also the number of abstracts accepted, which was 1,185. Regarding Travel and Stayment Grants, Dr. Eriksson reported that this year 117 Travel Grants and 19 Stayment Grants had been granted, totalling to $£ 44,200$. He offered his thanks to many people for their help and support and said he would warmly welcome feedback on this year's Meeting from the members.

Dr. Lefèbvre asked if the new format, namely the change from $3 \frac{1}{2}$ to 4 days, was experimental. If it was kept at 4 days he could foresee problems for the Pre- or Post-Symposia. Dr. Berger answered that the length of the Meeting was a decision for the local organisers in close cooperation with the EASD. He pointed out that the emphasis must remain on the main Meeting and as much as the pre- and post-symposia were appreciated, they were not official parts of the EASD Annual Meeting. Dr. Halban pointed out that the Meeting in effect lasted 5 days and questioned whether the ending could be on a Saturday enabling people to book cheaper air fares. Dr. Eriksson said that until then he had only heard positive comments about the longer meeting.

Then the question of a program for paramedical personnel was brought up. Dr. Berger replied that although the EASD liked to collaborate with these groups, he had to maintain that the EASD was an association of individual scientists and that research was the exclusive topic of the Annual Meeting. He said he was aware of the requests and they would be a matter for ongoing discussion.

Dr. Alberti then gave his strong approval for a 4 day meeting, this being especially good for the poster sessions which he had found brilliant. He suggested an immediate poll from the attendants. However, the President said that he was not sure if such a vote would be valid and he would prefer to discuss the pro's and con's and come to a decision later.

Dr. Krans mentioned the problem of nurses not being accepted for membership of the EASD.

Dr. Jörgens replied that no person who was working in medicine would be rejected. However, certain proof of scientific activities would be asked for.

When no further questions arose, the President asked Dr. Ferrannini for his report.

d) Editor-in-Chief, Diabetologia: Dr. Ferrannini informed the membership that the Editorial Office could now also be reached by e-mail. The staff in the Editorial Office had changed at the end of March when Ms P. Jackson left the office. Therefore, the staff had decreased to two full time positions, Ms S. Hills (Managing Editor) and Ms C. Baldocchi (Secretary), but on request extra secretarial help was available.

The Editor thanked the retired Associate Editors and announced the names of those who replaced them at the beginning of 1996: R. Bilous and A. I. Vinik while the new Advisory Board Members are E. Balasse, V. Grill, A. Naji and E. Standi.

Providing information on the editorial statistics, Dr. Ferrannini said that by the end of 1995 a total of 748 manuscripts had been received, an increase of $9 \%$. The projected figure for 1996 is 770. Regarding submissions Japan leads with 100 manuscripts, followed by UK and the USA. Compared to 1994 more manuscripts were received from Germany, Italy and France while the number of Sweden and Denmark decreased. Reflecting the increase in manuscripts the acceptance rate dropped from $32 \%$ in 1994 to $23 \%$ in 1995; the acceptance rate for Rapid Communications was $27 \%$. Along with 5 Review Articles and 11 For Debate articles, 2 Editorials and 53 letters were accepted for publication. The average number of days for Associate Editors' reports and for time needed to make an initial decision on acceptance/rejection had decreased to 53 and 61 days respectively. Springer needed about the same time for publication (121 days in 1995 vs 123 days in 1994). The overall time interval from receipt to publication had decreased from 9.3 to 8.7 months in 1995 .

A supplement issue on vascular complications of NIDDM will be published in November 1996.

Dr. Berger expressed his thanks to Dr. Ferrannini and asked the membership for comments. Dr. Nerup offered his congratulations to Dr. Ferrannini.

The President thanked the Editor-in-Chief for his report. 


\section{Elections}

a) Vice President 1997-2000: The Council's election of Dr. G.H. Tomkin as successor of Dr. P. Passa was unanimously approved.

b) Honorary Secretary: The prolongation of Dr. U.J. Eriksson's term of office by one year was unanimously approved.

c) Council Members 1997-2000: Drs. T. Halmos (H), M. Hod (Israel), D. Koev (Bulgaria) and I. Valverde (E) were unanimously elected by the General Assembly in place of retiring Council Members Drs J.S. Christiansen, R. Gomis, I. Kalits and $\mathrm{G}$. Schernthaner.

\section{Postgraduate Education Sub-Committee}

Since it had previously been decided not to hold a PGESC in Stockholm after the 1995 Annual Meeting, a three-day course was run in Birshtonas, Lithuania from 21-23 September and was attended by 130 doctors and specialist nurses. The meeting took the format of formal lectures with lively discussions and also interactive workshops with patient involvement.

The next Postgraduate Education Course was held near Graz, Austria, 21-24 March 1996 and was organised by Drs J. Skrha and T. Pieber. Again attendance and interaction of the audience were very good. Finally the PGESC supported a meeting in Marathon, Greece from 3-4 May 1996 for the Mediterranean countries. Immediately following this year's Annual Meeting a PGESC course for physicians, general practitioners and nurses was organised by Dr. J. Skrha in Prague, Czech Republic. Still being prepared were courses in Malta (1/97) and the Ukraine (4/97).

Dr. Berger offered his thanks and pointed out the importance of the PGESC.

\section{Study Groups}

The President announced a new EASD Study Group on Hypertension. Their first meeting was held in Padua, Italy and proceedings were printed in the August issue of Diabetologia.

Regarding the approach to found a Study Group on Psychosocial Aspects, Dr. Berger reported that an announcement had been included in the journal. The official approval for founding this Study Group was still outstanding, but an initial meeting which was held in Stockholm, Sweden, showed a considerable interest in this new Study Group.

\section{Honorary Membership}

Dr. Berger welcomed Dr. S. Rahbar and Dr. J. Pirart as new Honorary Members of the EASD. The Executive Committee had decided to honour these members for their remarkable research activities. The membership welcomed the new Honorary Members with applause.

Before ending the General Assembly, the President thanked the retiring Executive Committee Members Drs. J. Nunes Correa and K.F. Hanssen as well as those leaving the Council, Drs. M. Antsiferov, C. Berne, G. Pozza and F. Sodoyez-Goffeaux. He also welcomed the new Honorary Treasurer Dr. R. J. Heine (NL), the new Vice-President Dr. P.A. Halban $(\mathrm{CH})$ and the Council Members who were starting their term of office, Drs. B. Frier (UK), H. Ilkova (TR), M. Porta (I) and AJL Scheen (B).

The General Assembly was then brought to a close. 
Table 1. Consolidated accounts for the year ended 31. December 1995

\begin{tabular}{|c|c|c|}
\hline Average Exchange rate DM/£ & $£ 2.4816$ & $£ 2.262$ \\
\hline Income & 1994 & 1995 \\
\hline Membership fees incl. Diabetologia & 274,090 & 367,079 \\
\hline Donations & 100,834 & 181,434 \\
\hline Annual Meeting Surpluses & & 137,317 \\
\hline Bank interest & 35,262 & 36,743 \\
\hline Scientinsts Training Course & 1,956 & 2,632 \\
\hline Total & 412,142 & 725,205 \\
\hline Expenditure & 1994 & 1995 \\
\hline Salaries & 92,007 & 105,306 \\
\hline Rent & 7,434 & 7,298 \\
\hline Post, Phone/Fax, Printing & 24,083 & 24,201 \\
\hline Travel Expenses & 20,388 & 34,676 \\
\hline Office Costs, incl. Bank charges & 19,828 & 27,357 \\
\hline Extra office help & 1,102 & 1,139 \\
\hline Legal cost and accounting & 116 & 698 \\
\hline Annual Meeting expenses & 52,434 & 83,126 \\
\hline Free loans to Local Organisers & & 50,000 \\
\hline Travel and Stayment Grants & 43,477 & 55,472 \\
\hline Prizes (A.R. Fellowship, Eli Lilly, Minkowski, Mollegaard) & 40,487 & 67,110 \\
\hline Donation to country hosting the Annual Meeting & 66,313 & \\
\hline Donation others & 14,916 & 12,500 \\
\hline Diabetologia subscriptions & 272,804 & 257,956 \\
\hline Membership Directory & 16,984 & \\
\hline Editorial Office & 20,000 & 64,788 \\
\hline Other items incl. PGESC & 13,468 & 5,722 \\
\hline Scientists Training Course & 30,780 & 34,195 \\
\hline Total & 736,621 & 831,544 \\
\hline Cash at banks: & $\begin{array}{l}31.12 .1994 \\
£\end{array}$ & $\begin{array}{l}31.12 .1995 \\
£\end{array}$ \\
\hline \multicolumn{3}{|l|}{ Westminster Bank London } \\
\hline Current account & 500 & 500 \\
\hline Business Reserve account & 23,763 & 28,703 \\
\hline Money Market account & 563,000 & 380,000 \\
\hline Capital Reserve account & 23,766 & 4,667 \\
\hline \multicolumn{3}{|l|}{ Dresduer Bank Düsseldorf } \\
\hline Current account & 52,166 & 12,205 \\
\hline Money Market account & - & 76,560 \\
\hline Fixed ( 2 years) & & 59,896 \\
\hline \multicolumn{3}{|l|}{ Swiss Bank Corp. Geneva } \\
\hline Current account & 896 & 938 \\
\hline Money Market account & 48,027 & 55,789 \\
\hline Total $\mathrm{f}:$ & 712,118 & 619,258 \\
\hline
\end{tabular}

Year end exchange rates:

1994: £-DM 2.427 Sfr - DM 118.29

1995: £-DM 2.2205 Sfr-DM 124.64 
Table 2. Future EASD Annual Meetings

\begin{tabular}{lll}
\hline 1998 & 8-12 September & Barcelona, Spain \\
1999 & 28 September -2 October & Brussels, Belgium \\
2000 & & Jerusalem, Israel \\
2001 & & Birmingham, UK \\
2002 & & Budapest, Hungary \\
\hline
\end{tabular}

Table 3. Breakdown of membership by country compared to previous years (as of 31st December):

\begin{tabular}{|c|c|c|c|c|c|c|c|c|}
\hline & 1995 & 1994 & 1993 & 1992 & 1991 & 1990 & 1989 & 1988 \\
\hline Algeria & 2 & 4 & 4 & 1 & - & 1 & 1 & - \\
\hline Arger & 7 & 8 & 7 & 6 & 6 & 6 & 8 & 8 \\
\hline Australia & 69 & 62 & 66 & 61 & 54 & 52 & 48 & 42 \\
\hline ustria & 70 & 60 & 54 & 57 & 37 & 34 & 39 & 34 \\
\hline ijan (CIS) & 7 & 7 & - & - & - & - & - & - \\
\hline Bangl & 14 & 6 & 3 & 3 & 1 & 1 & 1 & 1 \\
\hline elgi & 144 & 133 & 154 & 161 & 140 & 138 & 140 & 111 \\
\hline olivia & 1 & 1 & - & - & - & - & - & - \\
\hline & 13 & 12 & 10 & 9 & 9 & 9 & 9 & 4 \\
\hline ria & 62 & 67 & 59 & 36 & 32 & 24 & 19 & 16 \\
\hline (CIS) & 3 & 4 & 1 & - & 1 & - & - & - \\
\hline $\mathrm{C}$ & 38 & 37 & 36 & 32 & 33 & 33 & 35 & 26 \\
\hline $\mathrm{C}$ & 1 & 1 & 1 & 1 & 1 & - & - & - \\
\hline $\mathrm{C}$ & 1 & - & 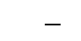 & - & - & - & - & - \\
\hline & 5 & 4 & 0 & 3 & 4 & 4 & 4 & 3 \\
\hline & 1 & 2 & 1 & 1 & 2 & 2 & 2 & 1 \\
\hline $\mathrm{C}$ & 2 & 2 & 1 & 1 & - & 1 & 1 & 1 \\
\hline $\mathrm{C}$ & - & 1 & 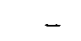 & 1 & 1 & 1 & 1 & - \\
\hline & 33 & 38 & 25 & 22 & 25 & - & - & - \\
\hline & 0 & & 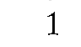 & - & - & - & & 1 \\
\hline & $r$ & 3 & 8 & 8 & 8 & 10 & 0 & 5 \\
\hline & 51 & 60 & 44 & 45 & 70 & 8 & 52 & 46 \\
\hline & 275 & 249 & 273 & 266 & 256 & 267 & 206 & 212 \\
\hline ep. & 2 & 2 & 1 & 1 & - & 1 & 1 & 1 \\
\hline & 1 & 1 & - & - & - & - & - & - \\
\hline & 23 & 20 & 11 & 12 & 12 & 13 & 9 & 8 \\
\hline & 1 & 8 & 7 & 6 & 5 & - & - & - \\
\hline & 102 & 96 & 93 & 100 & 95 & 97 & 87 & 68 \\
\hline & 229 & 205 & 217 & 218 & 222 & 252 & 254 & 237 \\
\hline & 3 & 2 & 2 & 1 & 1 & - & - & - \\
\hline & 435 & 416 & 363 & 350 & 315 & 319 & 262 & 220 \\
\hline & 145 & 138 & 126 & 125 & 131 & 118 & 122 & 82 \\
\hline & 1 & 1 & - & - & - & - & - & - \\
\hline & 1 & 1 & - & - & - & - & - & - \\
\hline & 62 & 63 & 58 & 56 & 48 & 42 & 41 & 34 \\
\hline & 1 & 0 & 8 & 9 & 6 & 7 & 8 & 6 \\
\hline It & 1 & 1 & 1 & 1 & 1 & - & 2 & - \\
\hline & 2 & - & - & - & - & - & - & - \\
\hline & 1 & 1 & 1 & 1 & - & - & - & - \\
\hline & 20 & 23 & 29 & 34 & 38 & 22 & 14 & 13 \\
\hline & 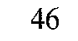 & 55 & 8 & 35 & 40 & 45 & 45 & 36 \\
\hline & 373 & 451 & 422 & 454 & 427 & 390 & 317 & 284 \\
\hline $\mathrm{Ja}$ & 112 & 86 & 76 & 62 & 52 & 49 & 40 & 32 \\
\hline Kazahkstan (CIS) & - & 2 & 3 & 3 & 1 & - & - & - \\
\hline Korea & 6 & 5 & 6 & 6 & 3 & 11 & 4 & 4 \\
\hline & 3 & 3 & 3 & 3 & 4 & 5 & 4 & 3 \\
\hline & 6 & 5 & 1 & 1 & - & - & - & - \\
\hline & 2 & 1 & 1 & 1 & 1 & 1 & 1 & 1 \\
\hline Lith & 12 & 12 & 10 & 9 & 9 & - & - & - \\
\hline Lux & 5 & 5 & 3 & 3 & 2 & 2 & 1 & 1 \\
\hline $\mathrm{Mac}$ & 1 & 1 & 1 & 1 & - & - & - & - \\
\hline on & 12 & 11 & 7 & 2 & - & - & - & - \\
\hline $\mathrm{Mal}$ & 1 & - & - & - & - & - & - & - \\
\hline Malta & 3 & 3 & 4 & - & - & - & - & - \\
\hline
\end{tabular}

\begin{tabular}{lrrrrrrrr}
\hline & 1995 & 1994 & 1993 & 1992 & 1991 & 1990 & 1989 & 1988 \\
\hline Mexico & 4 & 4 & 3 & 3 & 3 & 2 & 2 & 1 \\
Morocco & 1 & 2 & 2 & 2 & 3 & 3 & 3 & 1 \\
New Zealand & 9 & 8 & 10 & 10 & 11 & 7 & 5 & 5 \\
Norway & 102 & 70 & 105 & 76 & 68 & 72 & 62 & 56 \\
Oman & 2 & 1 & 1 & 1 & 1 & 1 & 1 & - \\
Pakistan & 6 & 5 & 3 & 2 & 2 & 2 & 1 & - \\
Panama & 1 & 1 & - & - & - & - & - & - \\
Paraguay & 2 & 2 & 1 & 1 & 1 & 1 & 1 & 1 \\
Peru & 2 & 2 & - & 1 & 1 & 2 & 2 & - \\
Philippines & 1 & 1 & 1 & 1 & 2 & 3 & - & - \\
Poland & 93 & 105 & 80 & 63 & 56 & 42 & 31 & 21 \\
Portugal & 97 & 97 & 105 & 55 & 57 & 54 & 53 & 40 \\
Puerto Rico & - & 1 & 1 & - & - & - & - & - \\
Qatar & 1 & 1 & - & - & - & 1 & 1 & 1 \\
Romania & 48 & 51 & 44 & 38 & 59 & 49 & 47 & 41 \\
Russia & 56 & 52 & 37 & 35 & 30 & - & - & - \\
Saudi Arabia & 8 & 14 & 17 & 19 & 9 & 8 & 9 & 10 \\
Singapore & 4 & 4 & 3 & 3 & 4 & 4 & - & - \\
Slovak Republik & 32 & 27 & 20 & - & - & - & - & - \\
Slovenia & 30 & 30 & 21 & 13 & 7 & - & - & - \\
South Africa & 14 & 26 & 27 & 35 & 27 & 29 & 10 & 8 \\
Spain & 199 & 172 & 162 & 152 & 131 & 122 & 109 & 96 \\
Sudan & 1 & 1 & 1 & 1 & 1 & 1 & 1 & - \\
Sweden & 353 & 250 & 310 & 337 & 270 & 253 & 265 & 219 \\
Switzerland & 75 & 79 & 86 & 85 & 104 & 110 & 110 & 101 \\
Tahiti & 1 & 1 & 1 & - & - & - & - & - \\
Taiwan & 10 & 10 & 12 & 8 & 7 & 6 & 4 & 3 \\
Tanzania & 2 & 2 & 2 & 1 & - & 1 & 1 & 1 \\
Tatarstan (CIS) & 1 & 1 & 1 & 1 & - & - & - & - \\
Thailand & 4 & 4 & 4 & 4 & 3 & 3 & 3 & 2 \\
The Netherlands & 232 & 245 & 213 & 180 & 151 & 150 & 141 & 123 \\
Tonga & - & 1 & 1 & 1 & - & - & - & - \\
Tunisia & 2 & 2 & 1 & 1 & 1 & - & - & 1 \\
Turkey & 38 & 42 & 32 & 21 & 13 & 11 & 11 & 9 \\
Ukraine (CIS) & 34 & 29 & 16 & 14 & 10 & - & - & - \\
United A Emirates & 1 & 2 & 3 & 1 & 2 & 2 & 1 & 1 \\
United Kingdom & 430 & 390 & 404 & 396 & 495 & 420 & 404 & 404 \\
USA & 264 & 239 & 232 & 209 & 199 & 169 & 165 & 164 \\
Uruguay & 1 & 1 & - & - & - & - & - & - \\
Uzbekistan (CIS) & 1 & 1 & 1 & 1 & 1 & 1 & 1 & 1 \\
Venezuela & 1 & 1 & - & - & - & - & - & - \\
Yugoslavia & 35 & 32 & - & 15 & 18 & 37 & 30 & 9 \\
Zimbabwe & 1 & 1 & 1 & 1 & 1 & 1 & 1 & 1 \\
\hline & & & & & & & \\
\hline
\end{tabular}

Table 4. Figures for membership at the end of 1995 compared to previous years:

as of 31st December:

1995199419931992199119901989198819871986198519841983 4650440642444000384736453317291823172181183919011677 